\title{
ANALISIS IMPLEMENTASI PROGRAM KELAS IBU HAMIL OLEH BIDAN PUSKESMAS DI KOTA MALANG
}

\author{
Jiarti Kusbandiyah \\ jiartikusbandiyah@gmail.com
}

Prodi Kebidanan STIKES Widyagama Husada

\begin{abstract}
ABTRACT
Maternal Mortality Rate ( MMR ) in Malang, East Java, is higher than that in 2010. (90.43). K4 Coverage in Malang decreased from $98.7 \%$ in 2009 to $87.1 \%$ in 2011 and is still below the target ( $95 \%$ ). Efforts to improve the coverage of K4 has been implemented since 2009 through the class of pregnant women but has yet to show optimal results. The results of preliminary studies indicate that the implementation class of pregnant women has not been going well. The purpose of this study was to analyze the factors that affect the implementation class of pregnant women by midwives clinic in the city of Malang. This research is an observational cross-sectional approach. Subjects were 25 midwives who organizes classes for pregnant women. Data were collected by interviews using a structured questionnaire and observation sheet. Bivariate analysis performed with the Fisher Exact test correlation, and multivariate logistic regression. The results showed the class of pregnant women has not been executed well by $40 \%$ of respondents. Standards and unclear policy goals for $32 \%$ of the respondents, the resources have not been adequate for $36 \%$ of respondents, communication between organizations is not going well for the $60 \%$ of respondents, characteristics of the implementing agencies have not been well for $72 \%$ of the respondents and the disposition has not been good by $32 \%$ of respondents. There is a relationship together between standard and policy objectives as well as the disposition of the class implementation to the implementation of programs of pregnant women. To correct class implementation pregnant women need to be disseminated more intensive classroom guidance of pregnant women, include independent midwife to hold classes for pregnant women as well as motivational enhancement midwife attitude towards the class to be more positive pregnant women
\end{abstract}

Keywords: Implementation, class of pregnant women and Midwivery 


\section{ABSTRAK}

Angka Kematian Ibu (AKI) di Malang lebih tinggi dari Jawa Timur yaitu 90,43 pada tahun 2010. Angka Cakupan K4 di Kota Malang menurun dari 98,7\% pada tahun 2009 menjadi 87,1\% pada tahun 2011 dan masih di bawah target (95\%). Upaya peningkatan cakupan K4 sudah dilaksanakan sejak tahun 2009 melalui kelas ibu hamil tetapi belum menunjukkan hasil yang optimal. Hasil studi pendahuluan menunjukkan bahwa pelaksanaan kelas ibu hamil belum berjalan dengan baik. Tujuan penelitian ini adalah menganalisis faktor-faktor yang berpengaruh terhadap implementasi kelas ibu hamil oleh bidan puskesmas di Kota Malang. Jenis penelitian ini adalah observasional dengan pendekatan cross sectional. Subjek penelitian adalah 25 bidan yang menyelenggarakan kelas ibu hamil. Data dikumpulkan dengan wawancara menggunakan kuesioner terstruktur dan lembar observasi. Analisis bivariat dlakukan dengan uji korelasi Fisher Exact dan multivariat dengan regresi logistik. Hasil penelitian menunjukkan kelas ibu hamil belum dilaksanakan dengan baik oleh $40 \%$ responden. Standar dan tujuan kebijakan belum jelas bagi 32\% responden, sumberdaya belum memadai bagi 36\% responden, komunikasi antar organisasi belum berjalan baik bagi $60 \%$ responden, karakteristik badan pelaksana belum baik bagi $72 \%$ responden dan disposisi belum baik oleh $32 \%$ responden. Ada hubungan bersama-sama antara standar dan tujuan kebijakan serta disposisi implementor dengan implementasi program kelas ibu hamil. Untuk memperbaiki implementasi kelas ibu hamil perlu dilakukan sosialisasi lebih intensif tentang pedoman kelas ibu hamil, menyertakan bidan praktek mandiri untuk menyelenggarakan kelas ibu hamil serta motivasi untuk peningkatan sikap bidan terhadap kelas ibu hamil supaya lebih positif.

\section{Kata Kunci : Implementasi, Kelas Ibu Hamil , Bidan Puskesmas}

\section{PENDAHULUAN}

Angka kematian Ibu (AKI) di Propinsi Jawa Timur pada tahun 2010 sebanyak 79,4/100.000 KH. AKI di Kota Malang terlihat lebih tinggi dari angka di Jawa Timur yaitu berturut-turut pada tahun 2009 sebanyak 120,5/100.000 KH, tahun 2010 sebanyak 79,2/100.000 KH dan meningkat lagi menjadi 90,4/100.000 $\mathrm{KH}$ pada tahun 2011. Penyebab kematian terbanyak di Kota Malang disebabkan oleh preeklamsi dan eklamsi sebanyak 36,3\%. ${ }^{1}$

Data PWS KIA dari tahun 2009-2011

di Kota Malang menunjukkan bahwa cakupan pelayanan $\mathrm{K} 1, \mathrm{~K} 4$, persalinan di tenaga kesehatan, persalinan di fasilitas kesehatan, deteksi resiko tinggi oleh masyarakat serta komplikasi yang ditangani belum mencapai target. Cakupan K1 sebesar 96,8\% dan K4 sebesar 87,1\% belum mencapai target yaitu $100 \%$ untuk K1 dan 95\% untuk K4. Angka cakupan K4 menurun dari 98,7\% pada tahun 2009 menjadi 87,1 pada tahun
2011. 1,2,3 Terdapat kesenjangan sekitar 9,1\% antara K1 dan K4.

Salah satu upaya untuk menurunkan kesenjangan antara $\mathrm{K} 1$ dan $\mathrm{K} 4$ tersebut adalah dicanangkannya program kelas ibu hamil. ${ }^{4}$ Program kelas ibu hamil di kota Malang mulai disosialisasikan sejak tahun 2008 dan sudah dilaksanakan sejak tahun 2009. Informasi yang didapatkan dari 15 puskesmas, menunjukkan bahwa dari 50 kelurahan yang di wilayah kerja mereka, baru $30(60 \%)$ yang memiliki kelas ibu hamil dengan rincian 5 puskesmas (33\%) telah memiliki kelas ibu hamil sesuai jumlah kelurahan, 8 puskesmas (53,4\%) belum semua kelurahan di wilayah kerjanya memiliki kelas ibu hamil dan 2 puskesmas $(13,3 \%)$ pernah melaksanakan program kelas ibu hamil tetapi kemudian tidak berjalan. Jika dibandingkan dengan kabupaten Malang, pelaksanaan kelas ibu hamil sudah lebih baik tetapi peserta kelas ibu hamil jauh lebih dengan sasaran ibu hamil karena 
banyak ibu hamil yang periksa ke bidan praktek mandiri sehingga tidak terdeteksi dan tidak mengikuti kelas ibu hamil.

Hasil studi pendahuluan yang dilakukan oleh peneliti dengan melakukan wawancara pada 5 bidan dan observasi pada 5 kelas ibu hamil di kota Malang didapatkan hasil bahwa bidan yang sudah dilatih telah mensosialisasikan hasil pelatihan kepada rekan kerja puskesmas tetapi tidak ke bidan praktek swasta yang ada di wilayah kerja mereka. Metode sosialisasi yang dilakukan bermacam-macam, sebagian besar $80 \%$ menyampaikan secara singkat dengan langsung memberikan materi kepada rekan kerja sehingga terdapat kemungkinan bidan yang disosialisasikan belum memahami secara mendalam dan $20 \%$ mensosialisasikan dalam bentuk pendampingan.

Dalam pelaksanaannya sasaran halhal yang belum sesuai sasaran ibu hamil, jumlah pertemuan sampai dengan lulus, tidak dilakukan pretes dan postes dengan menggunakan kuesioner untuk mengevaluasi hasil penyuluhan yang diberikan dan pemebelajaran yang kurang variatif atau monoton. Dari segi sumberdaya masih ada kendala masalah dana dan sarana prasaran penunjang food model, KB kit, matras untuk senam hamil, CD untuk senam hamil disediakan sendiri oleh puskesmas. Sampai dengan sekarang belum semua alat tersebut dimiliki dan digunakan dalam pelaksanaan kelas ibu hamil sehingga metode terbatas pada ceramah tanpa demonstrasi terkait dengan materi diatas serta tidak pernah dilakukan supervisi khusus kelas ibu hamil oleh dinas, hanya pemantauan melalui laporan yang diberikan setiap bulan. Tujuan penelitian ini adalah menganalisis implementasi program kelas ibu hamil oleh bidab puskesmas di Kota Malang.

\section{METODE PENELITIAN}

Jenis penelitian ini adalah observasional survey dengan pendekatan cross sectional, dilakukan untuk menjelaskan hubungan dan pengaruh antara variabel independen meliputi standar dan tujuan kebijakan, sumberdaya, komunikasi antar organisasi, karakteristik badan pelaksana, disposisi implementor dan variabel dependen yaitu implemntasi kelas ibu hamil. Data diambil dengan wawancara menggunakan kuesioner terstruktur dan lembar observasi. Sampel adalah 25 bidan puskesmas di Kota Malang yang menyelenggarakan kelas ibu hamil dan diambil secara purposive sampling. Variabel bivariat dianalisis dengan uji korelasi fisher exact sedangkan untuk mengetahui pengaruh mutivariat dengan regresi logistik. ${ }^{5}$

\section{HASIL DAN PEMBAHASAN}

Hasil penelitian ini meliputi karakteristik responden, implementasi program kelas ibu hamil serta faktor-faktor yang berhubungan dengan implementasi program kelas ibu hamil. Rerata usia responden 31,6 tahun, lama kerja 7,5 tahun dan sebagian besar responden (96\%) berpendidikan DIII Kebidanan.

Tabel 1. Distribusi Frekuensi Karakteristik Responden Berdasarkan Umur dan Lama Bekerja

\begin{tabular}{lcccc}
\hline Karakteristik & Minimum & Maksimum & Rerata & Simpangan Baku \\
\hline Umur (th)) & 23 & 48 & 31,6 & 7,4 \\
\hline Lama Kerja (th) & 1 & 30 & 7,5 & 7,3 \\
\hline
\end{tabular}




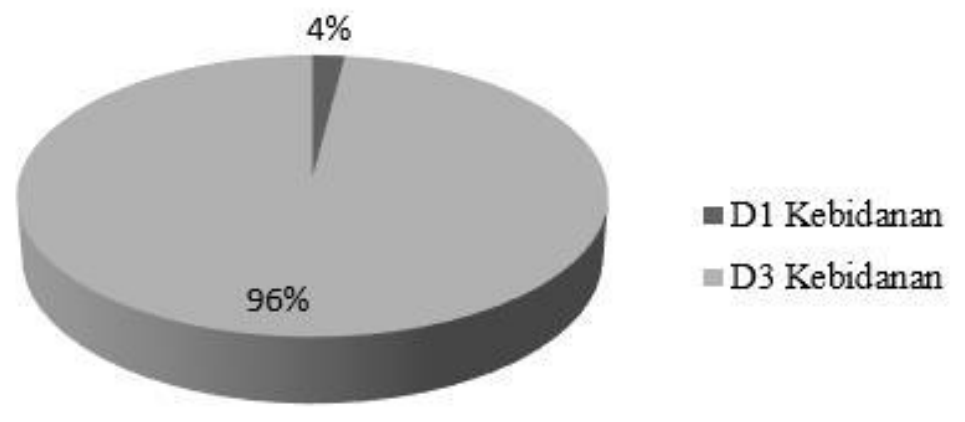

Gambar 1. Distribusi Frekuensi Responden Berdasarkan Pendidikan Terakhir

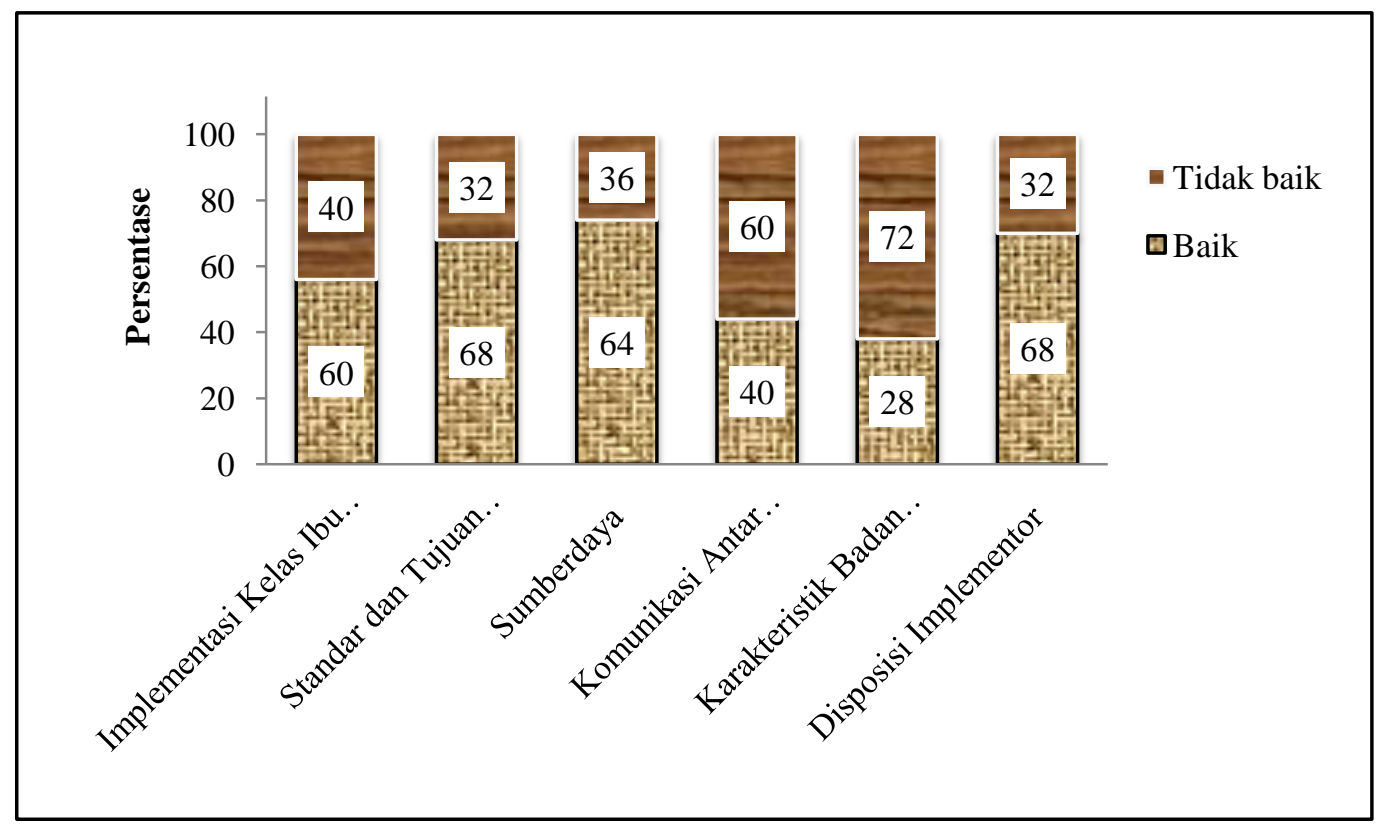

Gambar 2. Distribusi Frekuensi Variabel Penelitian Dalan Kategori

Tabel 2. Faktor yang Berhubungan dengan Implementasi Program Kelas Ibu Hamil oleh Bidan Puskesmas di Kota malang $(n=25)$

\begin{tabular}{|c|c|c|c|c|}
\hline \multirow{3}{*}{ Variabel } & \multirow{3}{*}{ Kategori } & \multicolumn{2}{|c|}{ Implementasi Kelas Ibu } & \multirow{3}{*}{ pvalue } \\
\hline & & & & \\
\hline & & Tidak Baik & Baik & \\
\hline \multirow[t]{2}{*}{ Standard dan Tujuan Kebijakan } & Tidak Jelas & $6(75 \%)$ & $2(25 \%)$ & \multirow{2}{*}{0,028} \\
\hline & Jelas & $4(23,5 \%)$ & $13(76,5 \%)$ & \\
\hline \multirow[t]{2}{*}{ Sumberdaya } & Tidak Memadai & $6(66,7 \%)$ & $3(33,3 \%)$ & \multirow{2}{*}{0,087} \\
\hline & Memadai & $4(25 \%)$ & $12(75 \%)$ & \\
\hline \multirow[t]{2}{*}{ Komunikasi antar Organisasi } & Tidak Baik & $6(40 \%)$ & $9(60 \%)$ & \multirow{2}{*}{1,000} \\
\hline & Baik & $4(40 \%)$ & $6(60 \%)$ & \\
\hline \multirow[t]{2}{*}{ Karakteristik Badan Pelaksana } & Tidak Baik & $9(50 \%)$ & $9(50 \%)$ & \multirow{2}{*}{0,179} \\
\hline & Baik & $1(14,3 \%)$ & $6(85,7 \%)$ & \\
\hline \multirow[t]{2}{*}{ Disposisi Implementor } & Tidak Baik & $7(87,5 \%)$ & $1(12,5 \%)$ & \multirow{2}{*}{0,002} \\
\hline & Baik & $3(17,6 \%)$ & $14(82,4 \%)$ & \\
\hline
\end{tabular}

Uji Fisher Exact 
Implementasi kelas ibu hamil sudah lebih dari separuh responden tetapi umumnya masih kurang pada rutininitas penyelenggaraan kelas ibu hamil. Pertemuan yang seharusnya diberikan tiga kali pertemuan sampai dengan dikatakan lulus seringkali hanya diberikan satu kali pertemuanpertemuannya sangat terbatas. Keikutsertaan suami cukup besar tetapi hanya sebatas melihat proses tanpa merespon dan mendengarkan materi. Metode yang digunakan dalam kelas ibu hamil hanya menggunakan lembar balik. Variasi metode jarang dilakukan sehingga terkesan monoton. Selain penyuluhan juga diberikan latihan tentang senam hamil di akhir sesi. Hal ini disebabkan karena kurangnya sulitnya ibu hamil untuk menghadiri kelas ibu hamil, oleh karena itu perlu upaya proaktif dari bidan, komunikasi yang baik serta kerjasama yang baik dengan kader untuk dapat memotivasi ibu hamil untuk bida hadir. Kurangnya dana dan sarana prasarana juga menjadi kendala sehingga pembelajaran tidak banyak menggunakan metode variatif, hal ini bisa menyebabkan ibu hamil menjadi bosan dan pengetahuan kurang tersampaikan dengan maksimal.

Menurut teori Van Meter dan Van Horn bahwa dalam implementasi suatu program, perlu dukungan dan koordinasi dengan instansi lain, dalam hal ini diperlukan komunikasi yang baik dan berkesinambungan. Perlu komunikasi yang baik supaya tujuan kebijakan bisa disampaikan dan dimengerti dengan baik. Variabel lain yang juga mempengaruhi adalah kecukupan sumberdaya mulai dari sumberdaya manusia, dana maupun sarana dan prasarana sehingga implementasi bisa sesuai yang diharapkan. Muaranya adalah sikap atau disposisi implementor, meskipun semua variabel baik tetapi pelaksananya kurang baik dalam menyikapi program, maka implementasi bisa terhambat pelaksanaannya. ${ }^{6}$
Standar dan tujuan kebijakan sudah baik/jelas bagi sebagian besar responden. Responden rata-rata mendapatkan informasi tentang standart dari sosialisasi bukan dari pelatihan sehingga beberapa responden ada yang belum pernah membaca atau tahu buku pedoman pelaksanaan kelas ibu hamil. Target yang diitetapkan oleh sebagian responden sulit terjangkau, penyebabnya adalah banyak ibu hamil yang tidak memeriksakan kehamilan ke bidan puskesmas tetapi ke bidan praktek swasta sehingga jumlah sasaran ibu hamil lebih sedikit dari yang seharusnya.

Menurut Grindle, tujuan kebijakan sangat menentukan program aksi dan proyek individu yang akan didesain dan didanai. Isi kebijakan harus mengedepankan kepentingan kelompok sasaran, tipe manfaat, derajad perubahan yang diinginkan, letak pengambilan keputusan dan sumberdaya yang dilibatkan. Dalam hal ini, penting ditentukan siapa pelaksana yang tepat untuk suatu program, jika banyak sasaran yang ditangani oleh bidan praktek mandiri, akan lebih baik jika penyelenggara kelas ibu hamil bukan hanya bidan puskesmas tetapi juga bidan praktek swasta. $^{7}$

Sumberdaya sudah memadai bagi sebagian besar responden, angka ini tinggi berdasarkan pengkajian sarana prasarana yang dimiliki. Sarana dan prasarana yang sudah baik terutama untuk ketersediaan lembar balik, buku KIA dan Stiker P4K karena alat tersebut yang selalu digunakan dalam penyelenggaraan kelas ibu hamil. Siker P4K sudah ada ada tetapi pelaksanaan untuk ditempel di rumah ibu hamil belum dilakukan secara maksimal. Jika dilihat dari sumberdana masih kurang terutama untuk konsumsi dan pengadaan alat penunjang. Dana biasanya diambil dari dana BOK, sebagian dana juga tersendat dan baru turun setelah ada laporan kegiatan.

Pada penelitian ini, sumberdaya tidak banyak berhubungan dengan keberhasilan implementasi kelas ibu hamil, 
hal ini tidak sejalan dengan penelitian yang dilaksanakan oleh Anggraeni dan Muazaroh yang menyimpulkan bahwa ada hubungan antara sumberdaya dengan implemntasi. ${ }^{8}$ Hal ini juga kurang sejalan dengan teori Van meter dan van Horn yang mengatakan bahwa sumberdaya dapat menunjang keberhasilan implementasi suatu program, semakin memadai sumberdaya maka semakin baik implementasi. Sumberdaya yang berkesinambungan antara tenaga, dana, sarana dan prasarana akan menghasilkan program yang baik. ${ }^{6}$

Disisi lain sumberdaya yang baik tetapi tidak disertai dengan sikap positif dari penyelenggara juga akan menyebabkan implementasi kurang berjalan optimal. Meskipun sumberdaya sudah optimal tetapi tidak dimanfaatkan atau digunakan dengan baik, maka implementasi juga tidak akan berjalan optimal

Komunikasi antar organisasi belum berjalan baik oleh sebagian responden. Belum adanya rapat rutin yang khusus untuk membahas kelas ibu hamil belum bisa dilakukan sehingga komunikasi hanya sebatas informasi yang disisipkan pada pertemuan rutin bulanan misalnya pada pertemuan kader. Pemberian feedback dari dinas kesehatan juga belum optimal sehingga responden mengalami kebingungan apakah kelas ibu hamil sudah berjalan dengan benar atau belum.

Menurut Edwards, keberhasilan impelementasi kebijakan mensyaratkan agar implementor mengetahuin apa yang akan disampaikan. Apa yang menjadi tujuan dan sasaran kebijakan harus ditransmisikan kepada kelompok sasaran sehingga mengurangi distorsi implementasi. Komunikasi berkenaan dengan bagaimana keputusan kebijakan atau perintah dikomunikasikan dengan tepat dan konsistensi terhadap organisasi/publik, harus jelas dan dapat diikuti. ${ }^{7}$

Karakteristik badan pelaksana sudah baik bagi bagi sebagian besar responden tetapi untuk masalah supervisi masih kurang tidak ada reward yang diberikan jika berhasil menyelenggarakan kelas ibu hamil dengan baik. Supervisi menurut Handoko berarti atasan mengarahkan, memimpin dan mempengaruhi bawahan. Secara sederhana adalah untuk membuat atau mendapatkan para karyawan yang menjadi bawahannya melakukan apa yang diinginkan, dan harus mereka lakukan dengan menggunakan kemampuan motivasi, komunikasi dan kepemimpinan untuk mengarahkan karyawan mengerjakan sesuatu yang ditugaskan kepada bawahannya. ${ }^{8}$ Pada umumnya para karyawan mendambakan bahwa kinerja mereka akan berkorelasi dengan imbalan-imbalan yang diperoleh dari organisasi. Para karyawan tersebut menentukan pengharapan-pengharapan mengenai imbalan-imbalan dan kompensasi yang diterima jika tingkat kinerja tertentu telah tercapai. ${ }^{9}$

Disposisi implementor sudah baik bagi sebagian besar responden. Responden sudah melaksanakan kelas ibu hamil dengan senang dan bertanggungjawab. Sedikit kelemahan adanya tidak adanya program kerja yang disusun untuk perencanaan penyelenggaraan kelas ibu hamil hal ini karena sulitnya menetapkan jumlah yang tepat dari sasaran kelas ibu hamil akibat banyak ibu hamil yang tidak terdeteksi karena periksa di bidan praktek swasta. Selain itu juga masih kurangnya upaya bidan untuk menggali dana diluar dana puskesmas.

Apabila implementor memiliki disposisi yang baik, maka dia akan dapat menjalankan kebijakan dengan baik seperti apa yang diinginkan oleh pembuat kebijakan. Ketika implementor memiliki sikap atau perspektif yang berbeda dengan pembuat kebijakan, maka proses implementasi kebijakan juga menjadi tidak efektif. Jika para pelaksana mempunyai kecenderungan sikap positif dan memberikan dukungan terhadap implementasi kebijakan maka terdapat kemungkinan besar implementasi kebijakan 
akan terlaksana sesuai dengan keputusan awal. Demikian sebaliknya, jika para pelaksana bersikap negatif atau menolak terhadap implementasi kebijakan karena konflik kepentingan maka implementasi kebijakan akan menghadapi kendala yang serius. ${ }^{7}$

Pada Tabel 2 dapat dilihat bahwa dengan menggunakan uji Fisher Exact, variable yang berhubungan secara bivariat adalah standar tujuan kebijakan dan disposisi implementor, sedangkan variabel yang lainnya tidak berhubungan. Jika dilihat dari nilai signifikansi, variabel standar dan tujuan kebijakan, sumberdaya, karakteristik badan pelaksana dan disposisi implementor memiliki nilai $p$-value $<0,25$ dapat dilanjutkan ke analisa multivariat.

Tabel 3. Hasil Analisis Statistik Multivariat Hubungan Bersama- sama Variabel Bebas Dengan Variabel Terikat.

\begin{tabular}{ccccccr}
\hline Variabel & B & SE & p-value & Exp.B & \multicolumn{2}{c}{ Exp.B } \\
\hline $\begin{array}{c}\text { Standar dan tujuan } \\
\text { kebijakan }\end{array}$ & 2.659 & 1.371 & .052 & 14.279 & .972 & 209.739 \\
$\begin{array}{c}\text { Disposisi } \\
\text { Implementor }\end{array}$ & 1.473 & 1.473 & .010 & 44.159 & 2.462 & 792.079 \\
$\quad$ Constant & -3.870 & 1.669 & 5.374 & .021 & & \\
\hline
\end{tabular}

Uji Regresi Logistik Berganda

Setelah dilakukan uji hubungan secara bersama-sama menggunakan regresi logistik, ternyata hanya variabel disposisi implementor (sikap pelaksana) yang memiliki p-value $0,010<0,05$. Kesimpulannya ada hubungan secara bersama antara disposisi implementor dengan implementasi program kelas ibu

na kebijakan harus merasa memiliki terhadap tugasnya masing-masing berdasarkan rencana yang telah ditetapkan sebelumnya.

Subarsono mengungkapkan kualitas dari suatu kebijakan dipengaruhi oleh kualitas atau ciri-ciri dari para aktor, kualitas tersebut adalah tingkat pendidikan, kompetensi dalam bidangnya, pengalaman kerja, dan integritas moralnya. ${ }^{11} \quad$ Karakteristik implementor seperti komitmen, kejujuran dan sikap demokratis akan menyebabkan organisasi dapat berfungsi lebih efisien dan efektif. Bila implementor memiliki disposisi yang baik maka dia akan dapat menjalankan kebijakan dengan baik. ${ }^{7,4}$

Menurut Edwards, kecenderungan pelaksana mencakup tiga hal penting yaitu respon implementor terhadap kebijakan, kognisi yakni pemahamannya terhadap kebijakan dan intensitas disposisi hamil. Sikap para pelaksana dalam menjalankan tugas dan tanggungjawab sebagai pelaksana kebijakan harus dilandasi dengan sikap disiplin. Hal tersebut dilakukan karena dapat mempengaruhi keberhasilan implementasi kebijakan, setiap badan/instansi pelaksa

implementor yakni preferensi nilai yang dimiliki implementor. Implementasi kebijakan yang berhasil harus diikuti kesadaran terhadap kebijakan tersebut secara menyeluruh. Hal ini berarti bahwa kegagalan suatu implementasi sering diakibatkan oleh ketidaktaatan pada pelaksana kebijakan atau dengan kata lain sikap yang kirang mendukung suatu kebijakan. Sikap merupakan reaksi atau respon yang masih tertutup dari seseorang terhadap suatu stimulus atau objek. Dengan kata lain, sikap adalah penilaian atau pendapat seseorang terhadap stimulus atau objek. Manifestasi sikap tidak dapat langsung dilihat, tetapi hanya dapat ditafsirkan terlebih dahulu dari perilaku yang tertutup. Newcomb, seorang ahli psikologi sosial menyatakan bahwa sikap itu merupakan kesiapan atau kesediaan 
untuk bertindak dan bukan merupakan motif tertentu. ${ }^{7}$

Menurut Azwar, sikap dikatakan sebagai suatu respon evaluatif. Respon hanya akan timbul apabila individu dihadapkan pada suatu stimulus yang menghendaki reaksi individual. Respon evaluatif berarti bahwa bentuk reaksi yang dinyatakan sebagai sikap itu timbul didasari oleh proses evaluasi dalam diri individu yang memberi kesimpulan terhadap stimulus dalam bentuk nilai baik buruk, positif negatif, menyenangkan tidak menyenangkan yang kemudian mengkristal sebagai potensi reaksi terhadap onjek sikap. Sebagian besar penelitian memperlihatkan adanya indikasi hubungan yang kuat antara sikap dengan perilaku. Jika sikap pelaksana positif terhadap kelas ibu hamil, maka perilaku untuk mengimplementasikan program tersebut juga akan baik, sebaliknya jika sikap pelaksana negatif, maka akan malas untuk melaksanakan program tersebut dengan optimal. ${ }^{12,13}$

Variabel standar dan tujuan kebijakan yang memiliki p-value 0,052 lebih besar sedikit dari 0,05 tetapi memiliki nilai Exp-B 14,729 artinya semakin baik standard dan tujuan kebijakan serta disposisi implementor, maka akan semakin baik pula implementasi kebijakan. Kejelasan standart sangat mempengaruhi keberhasilan kelas ibu hamil kemudian ditunjang dengan disposisi yang baik.

Standart dan tujuan kebijakan diperlukan untuk mengarahkan dalam melaksanakan kebijakan, hal tersebut dilakukan agar sesuai dengan program yang sudah direncanakan. Grindle menjelaskan bahwa keberhasilan implementasi ditentukan oleh apakah tujuantujuan telah dirumuskan secara jelas atau kabur.7 Apabila tujuan dan sasaran tidak jelas dan tidak diketahui sama sekali oleh kelompok sasaran, maka akan terjadi resistensi dari kelompok sasaran. ${ }^{10}$

Proses implementasi baru akan dimulai apabila tujuan dan sasaran telah ditetapkan. Program kegiatan telah tersusun dan dana telah siap dan telah disalurkan untuk mencapai sasaran. Oleh karena itu tugas implementasi adalah membentuk suatu kaitan (linkage) yang memudahkan tujuantujuan kebijakan bisa direalisasikan sebagai dampak dari suatu program pemerintah. Keberhasilan implementasi dipengaruhi oleh isi dari kebijakan yang mencakup sejauh mana kepentingan kelompok sasaran atau target sasaran termuat dalam sisi kebijakan, jenis manfaat yang diterima oleh sasaran, sejauh mana perubahan yang diinginkan dari sebuah kebijakan, apakah letak sebuah program sudah tepat, apakah kebijakan telah menyebutkan implementornya dengan rinci dan apakah sebuah program didukung oleh sumberdaya yang memadai.

Pada akhirnya kejelasan standard dan tujuan serta disposis implementor perlu diperbaiki guna meningkatkan implementasi kelas ibu hamil. Dengan peningkatan hal tersebut diharapkan kelas ibu hamil dapat bejalam maksimal dan secara tidak langsung berkontribusi untuk membantu penurunan Angka Kematian Ibu dan Bayi.

\section{KESIMPULAN}

Implementasi program kelas ibu hamil sudah dilaksanakan dengan baik oleh sebagian besar responden. Hal ini dipengaruhi oleh disposisi atau sikap bidan puskesmas terhadap pelaksanaan program kelas ibu hamil serta kejelasan standard dan tujuan kebijakan dari program kelas ibu hamil itu sendiri. Untuk memperbaiki implementasi kelas ibu hamil perlu dilakukan sosialisasi lebih tentang pedoman kelas ibu hamil, menyertakan bidan praktek mandiri untuk menyelenggarakan kelas ibu hamil serta motivasi untuk peningkatan sikap bidan terhadap kelas ibu hamil supaya lebih positif.

\section{DAFTAR PUSTAKA}

Dinas Kesehatan Kota Malang. Laporan PWS KIA.Malang.2009

Dinas Kesehatan Kota Malang. Laporan PWS KIA.Malang.2010

Dinas Kesehatan Kota Malang. Laporan PWS KIA. Malang, 2011 
Departemen Kesehatan RI. Indikator Indonesia sehat 2010 Visi baru, Misi, Kebijakan dan Strategi Pembangunan Kesehatan. Jakarta. 2004

Creswll, J. Research Design. Qualitative, Quantitative and Mixed Methods Approaches. Third Edition.Pustaka Pelajar.Yogyakarta. 2010

Horn, Vam Meter. The Policy Implementation Process: A Conceptual Framework. 1975

Winarno, B. Kebijakan Publik Teori dan Proses edisi revisi. Media Pressindo. Yogyakarta. 2008.

Gibson J.,Ivancevich J.,\& Donelly J. Organization Behavior Structure and Processes. $5^{\text {th }}$ ed. Texas Business Publications Inc, 1990

Handoko, TH. Manajemen Personalia dan Sumber Daya Manusia, Edisi 2. BPFE, Jakarta, 1995

Wiyono, D. Manajemen Kepemimpinan dan Organisasi Kesehatan. Penerbit Airlangga University Press. Surabaya. 1997

Subarsono, AG. Analisis Kebijakan Publik. Edisi kedua. Gadjah Mada University Press. Yogyakarta. 2006

Azwar, Saifuddin.Sikap Manusia, Teori dan Pengukurannya. Pustaka Pelajar. 2009

Puji Hastuti, dkk. Efektifitas pelatihan kelas ibu hamil untuk meningkatkan pengetahuan, sikap, keterampilan dan kunjungan Antenatal Care. Jurnal penelitian kesehatan suara forikes. Volume II nomor 2: ISSN:2086-3098. 2011 